Review Article

\title{
Upper limb function evaluation scales for individuals with cerebral palsy: a systematic review
}

\author{
Cibele Almeida Santos ${ }^{1 *}$, Renata Calhes Franco de Moura ${ }^{1)}$, Roberta Delasta Lazzari ${ }^{1)}$, \\ Arislander Jonathan Lopes Dumont ${ }^{1}$, Luiz Alfredo Ferreira Braun ${ }^{1}$, \\ Claudia Santos Oliveira ${ }^{1)}$ \\ 1) Movement Analysis Lab, University Nove/UNINOVE: Av Dr Afonso Pinto, 109-Barra Funda-São \\ Paulo, CEP: 01156-050, Brazil
}

\begin{abstract}
Purpose] The aim of the present study was to perform a systematic review of the literature on the scales and methods most often used for the evaluation of upper limb function in individuals with cerebral palsy. [Materials and Methods] Searches were conducted in the Medline, PEDro, Lilacs, Scielo, and PubMed databases. The following inclusion criteria were used for the selection of articles: randomized controlled study, evaluation of upper limb function in individuals with cerebral palsy, and publication between 2006 and 2014. The methodological quality of the articles was evaluated using the PEDro evidence scale. [Results] Five articles met the inclusion criteria and achieved 6 points or higher on the PEDro scale of methodological quality. [Conclusion] The studies analyzed used different evaluation scales, but no consensus has been reached thus far on which scale is the most appropriate. Thus, further studies are needed to establish an adequate method for the evaluation of upper limb function in individuals with cerebral palsy.

Key words: Cerebral palsy, Scale function, Upper limbs
\end{abstract}

(This article was submitted Oct. 20, 2014, and was accepted Jan. 11, 2015)

\section{INTRODUCTION}

Cerebral palsy (CP) describes set of permanent, mutable, motor development disorders that originate from a primary brain lesion and cause secondary musculoskeletal problems and limitations with regard to activities of daily living ${ }^{1)}$. Despite the consensus regarding the occurrence of sensory, motor, and functional impairments in children with $\mathrm{CP}^{2,3)}$, various methods have been used in the evaluation of these aspects $^{4}$.

Upper limb impairment occurs in $50 \%$ to $70 \%$ of individuals with $\mathrm{CP}^{5,6}$. Spasticity, muscle weakness, and insufficient motor control can give rise to secondary musculoskeletal complications, such as contractures and deformities, which result in limited movements ${ }^{7}$. Thus, the identification of factors that lead to functional impairment is of fundamental importance to clinical decision making and the evaluation of the effects of therapeutic strategies ${ }^{4)}$.

A study by Bae et al. ${ }^{8}$ ) showed that as the tissue compliance of spastic muscles at relaxation increases, muscle tone decreases and muscle activity increases, and spasticity leads to a lower moment-angle ${ }^{9}$. A number of treatments performed in either the home or school setting are proposed

*Corresponding Author. Cibele Almeida Santos (E-mail:

ci_bele.santos@ig.com.br)

(c)2015 The Society of Physical Therapy Science. Published by IPEC Inc. This is an open-access article distributed under the terms of the Creative Commons Attribution Non-Commercial No Derivatives (by-ncnd) License $<$ http://creativecommons.org/licenses/by-nc-nd/3.0/> . to improve function ${ }^{10)}$. However, the effectiveness of such therapies depends on well-conducted functional evaluation and patient fitness ${ }^{11,12)}$. Methods and tools developed for the evaluation of function have been used in individuals with $\mathrm{CP}$, such as the House Scale ${ }^{13}$, the Pediatric Evaluation of Disability Inventory ${ }^{14)}$, the Melbourne Assessment ${ }^{15)}$, the Pediatric Outcome D Collection Instrument ${ }^{16)}$, the Assisting Hand Assessment ${ }^{17}$, ABILHAND-Kids ${ }^{18)}$, and the Shriners Hospital for Children Upper Extremity Evaluation ${ }^{19)}$. While some of these measures have been validated, no consensus has been reached as to the best evaluation method for identifying improvements in upper limb function in individuals with $\mathrm{CP}^{20)}$. Yu et al. ${ }^{21)}$ believes that detailed and diverse investigations should be performed by considering the number and characteristics of subjects.

The aim of the present study was to perform a systematic review of the literature on the scales and methods most often used for the evaluation of upper limb function in individuals with $\mathrm{CP}$.

\section{MATERIALS AND METHODS}

Searches were conducted in the Medline, PEDro, Lilacs, Scielo, and PubMed databases using combinations of the following key words: "cerebral palsy," "upper limb/extremity," and "functional scales." The articles retrieved were evaluated independently by two researchers. The following inclusion criteria were used for the selection of articles: randomized controlled study, evaluation of upper limb function in individuals with $\mathrm{CP}$, and publication between 2006 and 2014. 
The methodological quality of the articles was evaluated using the Physiotherapy Evidence Database (PEDro) scale. The PEDro scale has 11 items, each of which receives a score of either 0 or 1 , except item 1 , which is not scored. The final score ranges from 0 to 10 points. This scale is used to evaluate the methodological quality of randomized, controlled, clinical trials with regard to two important factors as follows: whether the study has internal validity (whether the results offer sufficient information), and whether the study has both clinical and statistical relevance for a clear interpretation of the results and reproduction by other researchers. Any divergence in opinion between the two researchers was discussed until a consensus was reached on the score of the study in question.

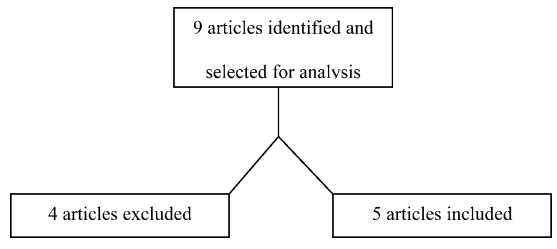

Fig. 1. Flowchart of the studies included in the literature review

Table 1. Articles included in the literature review

\begin{tabular}{cccc}
\hline Article & $\begin{array}{c}\text { Author and year of } \\
\text { publication }\end{array}$ & PEDro & Type of Study \\
\hline 1 & Koman et al., 2013 22$)$ & $7 / 10$ & Clinical trial \\
2 & Fedrizzi et al., 2013 ${ }^{23)}$ & $9 / 10$ & Clinical trial \\
3 & Xu et al., 2012 24$)$ & $8 / 10$ & Clinical trial \\
4 & Lin et al., 201125) & $7 / 10$ & Clinical trial \\
5 & Redman et al., 2008 & $6 / 10$ & Clinical trial \\
\hline
\end{tabular}

\section{RESULTS}

The database search resulted in the retrieval of nine articles, four of which failed to meet the inclusion criteria (Fig. 1). The five articles included in the present review had PEDro scores of 6 to 9 points (demonstrating methodological adequacy) and addressed the use of upper limb evaluation measures for individuals with CP (Tables 1 and 2). The five studies involved 296 male and female individuals aged 2 to 18 years who were diagnosed with CP. All of the studies used one or more measures to evaluate upper limb function. Table 3 displays the general characteristics (sample size, sample characteristics, and methods) and outcomes of the studies analyzed.

\section{DISCUSSION}

Among the upper limb function evaluation measures available in the literature, few are specific to individuals

Table 2. Scores of the articles included in the literature review

\begin{tabular}{lccccc}
\hline PEDro & 1 & 2 & 3 & 4 & 5 \\
\hline Eligibility & $\mathrm{N}$ & $\mathrm{Y}$ & $\mathrm{Y}$ & $\mathrm{Y}$ & $\mathrm{Y}$ \\
Randomized allocation & $\mathrm{Y}$ & $\mathrm{Y}$ & $\mathrm{Y}$ & $\mathrm{Y}$ & $\mathrm{Y}$ \\
Confidential allocation & $\mathrm{Y}$ & $\mathrm{Y}$ & $\mathrm{Y}$ & $\mathrm{Y}$ & $\mathrm{Y}$ \\
Similar prognosis & $\mathrm{N}$ & $\mathrm{Y}$ & $\mathrm{Y}$ & $\mathrm{N}$ & $\mathrm{Y}$ \\
Blinded subjects & $\mathrm{Y}$ & $\mathrm{Y}$ & $\mathrm{N}$ & $\mathrm{N}$ & $\mathrm{N}$ \\
Blinded therapists & $\mathrm{N}$ & $\mathrm{N}$ & $\mathrm{N}$ & $\mathrm{N}$ & $\mathrm{N}$ \\
Blinded evaluators & $\mathrm{Y}$ & $\mathrm{Y}$ & $\mathrm{Y}$ & $\mathrm{Y}$ & $\mathrm{N}$ \\
Key results & $\mathrm{Y}$ & $\mathrm{Y}$ & $\mathrm{Y}$ & $\mathrm{Y}$ & $\mathrm{N}$ \\
Comparison between groups & $\mathrm{Y}$ & $\mathrm{Y}$ & $\mathrm{Y}$ & $\mathrm{Y}$ & $\mathrm{Y}$ \\
Precision and variability & $\mathrm{Y}$ & $\mathrm{Y}$ & $\mathrm{Y}$ & $\mathrm{Y}$ & $\mathrm{Y}$ \\
Score & $7 / 10$ & $9 / 10$ & $8 / 10$ & $7 / 10$ & $6 / 10$ \\
\hline Y: yes; N: no & & & & &
\end{tabular}

Table 3. Characteristics of the studies included in the literature review

\begin{tabular}{|c|c|c|c|c|}
\hline Article & $\begin{array}{c}\text { No. of } \\
\text { subjects }\end{array}$ & $\begin{array}{c}\text { Characteristics } \\
\text { of sample }\end{array}$ & Methods & Outcomes \\
\hline 1 & 71 & $\begin{array}{c}\text { Spastic } \\
\text { hemiparesis }\end{array}$ & $\begin{array}{l}\text { EG: } 36-\text { Botulinum toxin } \\
\text { CG: } 35 \text { - Placebo injection }\end{array}$ & $\begin{array}{l}\text { The EG achieved a better wrist extension result in the Melbourne As- } \\
\text { sessment of Unilateral Upper Limb Function than the CG. }\end{array}$ \\
\hline 2 & 105 & $\begin{array}{c}\text { Spastic } \\
\text { hemiparesis }\end{array}$ & $\begin{array}{l}\text { EG1: } 34-\text { Intensive two-hand } \\
\text { training } \\
\text { EG2: } 33 \text { - Modified CIT } \\
\text { CG: } 33 \text { - Standard treatment }\end{array}$ & $\begin{array}{l}\text { The modified CIT group achieved better movement quality in the } \\
\text { QUEST than in the other groups and exhibited better quality of life, as } \\
\text { measured by the Besta scale. }\end{array}$ \\
\hline 3 & 75 & $\begin{array}{c}\text { Spastic } \\
\text { hemiparesis }\end{array}$ & $\begin{array}{l}\text { EG1: } 25 \text { - CIT } \\
\text { EG2: } 24-\text { CIT + electrical } \\
\text { stimulation } \\
\text { CG: } 26 \text { - Occupational therapy }\end{array}$ & $\begin{array}{l}\text { Among all the groups, EG2 demonstrated the best results for the upper } \\
\text { extremity functional test and grasping subtest of the Peabody develop- } \\
\text { mental motor scales. }\end{array}$ \\
\hline 4 & 22 & $\begin{array}{c}\text { Spastic } \\
\text { hemiparesis }\end{array}$ & $\begin{array}{l}\text { EG: 11- CIT } \\
\text { CG: 11- Control intervention }\end{array}$ & $\begin{array}{l}\text { The EG achieved better results in the PMDS-2, BOTMP, and PMAL } \\
\text { than in the CG. }\end{array}$ \\
\hline 5 & 23 & $\begin{array}{c}\text { Spastic } \\
\text { hemiparesis }\end{array}$ & $\begin{array}{l}\text { EG: 12- Botulinum toxin } \\
\text { CG: 11- Placebo injection }\end{array}$ & $\begin{array}{l}\text { No statistically significant differences were found between the groups. } \\
\text { Intraclass concordance was found for daily activities, speaking, and } \\
\text { communication on the Pediatric Quality of Life Inventory. }\end{array}$ \\
\hline
\end{tabular}

EG: experimental group; CG: control group; CIT: constraint-induced therapy; QUEST: Quality Upper Extremity Skill Test; PMDS-2: Peabody Motor Developmental Scales II; BOTMP: Bruininks-Oseretsky Test of Motor Proficiency; PMAL: Pediatric Motor Activity $\log$ 
with $\mathrm{CP}$, as most scales are standardized for use on adult stroke survivors. Despite the similarities between the two types of brain lesions, specificity is needed for the evaluation and treatment of these groups of patients. The articles analyzed in the present systematic review demonstrate the scarcity of studies on upper limb function in individuals with $\mathrm{CP}$, especially with regard to evaluation measures.

According to Koman et al. ${ }^{22)}$, the Melbourne Assessment of Unilateral Upper Limb Function scale provides objective measures of upper limb function, allows the assessment of the quality of upper limb movements, and demonstrates moderate to high consistency as an evaluation method. Therefore, this scale is widely used by occupational therapists in clinical practice.

All of the studies analyzed emphasized the evaluation of upper limb function associated with a functional therapeutic method or neurolytic block. Fedrizzi et al. ${ }^{23}$ ) applied the Quality Upper Extremity Skill Test (QUEST) and the Besta Scale, which demonstrated good performance and applicability. The QUEST allows an assessment of the quality of one- and two-hand movements in individuals with $\mathrm{CP}$ but does not allow an assessment of quality of life. The Besta Scale is used for the assessment of quality of life, as well as functional capacity and movement performance. Thus, the two scales complement one another in the evaluation of function.

$\mathrm{Xu}$ et al. ${ }^{24)}$ used the Upper Extremity Functional Test to assess function, dexterity, and movement efficiency, and the Grasping Subtest of Peabody Developmental Motor Scales, which is also known as the Peabody Developmental Motor Scales 2 or PDMS 2, for the two-hand evaluation. In the literature, the PDMS-2 is used less than the Upper Extremity Functional Test. However, the authors do not state whether one of the two scales is more applicable than the other.

Lin et al. ${ }^{25)}$ also used the PDMS-2 and the BruininksOseretsky Test of Motor Proficiency (BOTMP) for the assessment of range of motion and the Pediatric Motor Activity Log (PMAL) to quantify functional capacity, along with the Caregiver Functional Use Survey for the evaluation of caregivers. Improvements in unilateral and bilateral skills were demonstrated by the PMAL, but not the BOTMP. However, positive results were also demonstrated with use of the PDMS-2. The study reports the use of scales that allows the evaluation of functional capacity in children with $\mathrm{CP}$ but does not suggest that any particular scale is more favorable in clinical practice due to its greater applicability or the greater reliability of its results.

Redman et al. ${ }^{26)}$ analyzed the use of the Pediatric Quality of Life (PedsQL) scale. Although the authors demonstrated the applicability of this scale for individuals with $\mathrm{CP}$, the PedsQL is not sufficiently sensitive for the detection of small but clinically important changes and has no subscales for the evaluation of upper limb function.

Few studies have addressed the use of assessment measures for upper limb function in individuals with $\mathrm{CP}$. The studies analyzed in the present systematic review used different measures, and no consensus has been reached on the most appropriate scale or which has ideal clinical applicability in this population. Therefore, further studies on this issue are needed to allow the evaluation of upper limb function in individuals with CP by using well-defined methods that provide reliable information.

\section{ACKNOWLEDGEMENT}

We gratefully acknowledge the financial support from the National Council for Scientific and Technological Development (CNPq), Higher Education Personnel Training Coordination (CAPES) and Foundation of the State of São Paulo - FAPESP (Process: 2013/13767-8).

\section{REFERENCES}

1) Rosenbaum P, Paneth $\mathrm{N}$, Leviton A, et al.: A report: the definition and classification of cerebral palsy April 2006. Dev Med Child Neurol Suppl, 2007, 109: 8-14. [Medline]

2) Vasconcelos RL, Moura TL, Campos TF, et al.: Avaliação do desempenho funcional de crianças com paralisia cerebral de acordo com níveis do comprometimento motor. Rev Bras Fisioter, 2009, 13: 390-397. [CrossRef]

3) Manoel EJ, Oliveira JA: Motor developmental status and task constraint in overarm throwing. J Hum Mov Stud, 2000, 39: 359-378.

4) Oliveira MC: Avaliação Da Sensibilidade, Função Motora De Membros Superiores E Desempenho Funcional De Crianças Portadoras De Paralisia Cerebral. [Dissertação]. Campinas: Universidade Estadual de Campinas, 2007.

5) Elvrum AK, Brændvik SM, Sæther R, et al.: Effectiveness of resistance training in combination with botulinum toxin-A on hand and arm use in children with cerebral palsy: a pre-post intervention study. BMC Pediatr, 2012, 12: 91. [Medline] [CrossRef]

6) Uvebrant P: Hemiplegic cerebral palsy. Aetiology and outcome. Acta Paediatr Scand Suppl, 1988, 345: 1-100. [Medline] [CrossRef]

7) Vaz DV, Cotta Mancini M, Fonseca ST, et al.: Muscle stiffness and strength and their relation to hand function in children with hemiplegic cerebral palsy. Dev Med Child Neurol, 2006, 48: 728-733. [Medline] [CrossRef]

8) Bae SH, Kim KY: The effect of vibratory stimulation on tissue compliance and muscle activity in elbow flexor spasticity. J Phys Ther Sci, 2012, 8: 751-754. [CrossRef]

9) Fonseca LA, Grecco LA, Politti F, et al.: Use a portable device for measuring spasticity in individuals with cerebral palsy. J Phys Ther Sci, 2013, 3: 271-275. [CrossRef]

10) Boyd RN, Morris ME, Graham HK: Management of upper limb dysfunction in children with cerebral palsy: a systematic review. Eur J Neurol, 2001, 8: 150-166. [Medline] [CrossRef]

11) Steenbergen B: Using the MACS to facilitate communication about manual abilities of children with cerebral palsy. Dev Med Child Neurol, 2006, 48: 948-948. [Medline] [CrossRef]

12) Pagliano E, Andreucci E, Bono R, et al.: Evolution of upper limb function in children with congenital hemiplegia. Neurol Sci, 2001, 22: 371-375. [Medline] [CrossRef]

13) House JH, Gwathmey FW, Fidler MO: A dynamic approach to the thumbin palm deformity in cerebral palsy. J Bone Joint Surg Am, 1981, 63: 216225. [Medline]

14) Feldman AB, Haley SM, Coryell J: Concurrent and construct validity of the Pediatric Evaluation of Disability Inventory. Phys Ther, 1990, 70: 602-610. [Medline]

15) Johnson LM, Randall MJ, Reddihough DS, et al.: Development of a clinical assessment of quality of movement for unilateral upper-limb function. Dev Med Child Neurol, 1994, 36: 965-973. [Medline] [CrossRef]

16) McMulkin ML, Baird GO, Gordon AB, et al.: The pediatric outcomes data collection instrument detects improvements for children with ambulatory cerebral palsy after orthopaedic intervention. J Pediatr Orthop, 2007, 27: 1-6. [Medline] [CrossRef]

17) Krumlinde-Sundholm L, Holmefur M, Kottorp A, et al.: The Assisting Hand Assessment: current evidence of validity, reliability, and responsiveness to change. Dev Med Child Neurol, 2007, 49: 259-264. [Medline] [CrossRef]

18) Arnould C, Penta M, Renders A, et al.: ABILHAND-Kids: a measure of manual ability in children with cerebral palsy. Neurology, 2004, 63: 10451052. [Medline] [CrossRef]

19) Davids JR, Peace LC, Wagner LV, et al.: Validation of the Shriners Hospital for Children Upper Extremity Evaluation (SHUEE) for children with hemiplegic cerebral palsy. J Bone Joint Surg Am, 2006, 88: 326-333. 
[Medline] [CrossRef]

20) Gong HS, Chung CY, Park MS, et al.: Functional outcomes after upper extremity surgery for cerebral palsy: comparison of high and low manua ability classification system levels. J Hand Surg Am, 2010, 35: 277-283.e1, 3. [Medline] [CrossRef]

21) Yu J, Kang H, Jung J: Effects of modified constraint-induced movement therapy on hand dexterity, grip strength and activities of daily living of children with cerebral palsy: a randomized control trial. J Phys Ther Sci, 2012, 24: 1029-1031. [CrossRef]

22) Koman LA, Smith BP, Williams R, et al.: Upper extremity spasticity in children with cerebral palsy: a randomized, double-blind, placebo-controlled study of the short-term outcomes of treatment with botulinum A toxin. J Hand Surg Am, 2013, 38: 435-46.e1. [Medline] [CrossRef]

23) Fedrizzi E, Rosa-Rizzotto M, Turconi AC, et al. GIPCI Study Group: Unimanual and bimanual intensive training in children with hemiplegic cere- bral palsy and persistence in time of hand function improvement: 6-month follow-up results of a multisite clinical trial. J Child Neurol, 2013, 28: 161-175. [Medline] [CrossRef]

24) $\mathrm{Xu} \mathrm{K}$, Wang L, Mai J, et al.: Efficacy of constraint-induced movement therapy and electrical stimulation on hand function of children with hemiplegic cerebral palsy: a controlled clinical trial. Disabil Rehabil, 2012, 34: 337-346. [Medline] [CrossRef]

25) Lin KC, Wang TN, Wu CY, et al.: Effects of home-based constraint-induced therapy versus dose-matched control intervention on functional outcomes and caregiver well-being in children with cerebral palsy. Res Dev Disabil, 2011, 32: 1483-1491. [Medline] [CrossRef]

26) Redman TA, Finn JC, Bremner AP, et al.: Effect of upper limb botulinum toxin-A therapy on health-related quality of life in children with hemiplegic cerebral palsy. J Paediatr Child Health, 2008, 44: 409-414. [Medline] [CrossRef] 